Fecha de recepción: mayo 2021 Fecha de aceptación: junio 2021 Versión final: julio 2021

\section{El sobreviviente en documentales sobre juicios por violación a los derechos humanos en Argentina. Una aproximación a la construcción identitaria y los procesos de identificación en las representaciones audiovisuales}

Mariné Nicola ${ }^{(1)}$

\begin{abstract}
Resumen: El objetivo de este trabajo es hacer un recorrido sobre la imagen del "sobreviviente" que se construye en films documentales que representan los juicios por violación a los derechos humanos durante la última dictadura cívico-militar en Argentina. Desde mediados de la década del ' 80 hasta nuestros días podemos constatar desplazamientos en la imagen que se representa en los audiovisuales en torno al sobreviviente. Esto se vincula con procesos colectivos de identificación, donde el "otro" funciona como marco referencial permitiendo a los sujetos legitimarse en la misma oposición, a partir de la diferenciación.

En un primer momento, los sobrevivientes tienen nombre pero no rostro, en el Juicio a las Juntas de Comandantes (1985) son testigos de espaldas a la cámara, con una adscripción identitaria asociada a la identidad personal que los muestra como víctima de diferentes torturas y vejámenes, y desprovistos de intereses, compromisos y luchas. Con el transcurso del tiempo se restituye a los detenidos desaparecidos la filiación política, y se los aborda como sujetos enmarcados en luchas ideológicas e interacciones sociales, de esta forma se complejiza la identidad del sujeto, y se lo aborda como un actor social contextualizado. El corpus de audiovisuales documentales que representan los juicios por violación a los derechos humanos durante la última dictadura cívico-militar en Argentina está constituido por: "Señores, ¡de pie!” (1986); "El juicio” (1989); "El juicio que cambió al país” (1995); "ESMA: el día del juicio" (1998); "Juicio a las Juntas. El Nüremberg argentino" (2002); "Los días del juicio" (2010); "Proyecciones de la memoria" (2011).

En este artículo se indagará en la construcción de la identidad del sobreviviente, a partir del análisis de estos registros audiovisuales, abordándolo en tanto sujeto colectivo, entendiendo que la reflexión en torno a los sobrevivientes es necesaria, como tarea hacia el pasado pero también, en pos del presente, de los derechos humanos, la justicia y la memoria.
\end{abstract}

Palabas clave: identidad - sobreviviente - documentales - representación - juicios.

[Resúmenes en inglés y portugués en la página 39] 
(1) Profesora en Historia (UNL). Especialista en Docencia Universitaria (UNL). Doctoranda en Ciencias Sociales (UNER). Profesora adjunta en cátedras universitarias de la UNL. Investigadora del Centro de Investigaciones en Estudios Culturales, Educativos, Históricos y Comunicacionales (UNL). Dirige el proyecto CAI+D 2020 "La cultura en perspectiva histórica. Aportes de los estudios culturales a la investigación" (UNL). Es directora y coordinadora de la revista Culturas. Debates y perspectivas de un mundo en cambio (FHUC-UNL).

\section{En búsqueda del punto de sutura entre la representación de identidades y los procesos de identificación.}

En Argentina hay una amplia producción fílmica que realiza una relectura de la historia reciente e interviene en el complejo proceso de resignificar el pasado, en este sentido, podemos visualizar un amplio espectro de documentales políticos, antropológicos, testimoniales, subjetivos que representan la última dictadura cívico-militar desde distintos lentes y miradas, estableciendo y problematizando continuas relaciones pasado-presente en el proceso de construcción de la memoria.

El presente trabajo se propone indagar en torno a las representaciones documentales producidas a partir de 1985 sobre los juicios por los delitos de violación a los derechos humanos cometidos por civiles y militares durante la última dictadura en Argentina, poniendo en relación/ tensión la construcción de los procesos de identificación; debido a que los sobrevivientes, que fueron detenidos desaparecidos, se constituyen en el presente en testigos de los procesos judiciales.

El foco de la investigación se condensa, entonces, en la representación de los juicios; y en las tramas narrativas en cuyo interior pujan los testimonios, "En el lenguaje del sentido común, la identificación se construye sobre la base del reconocimiento de algún origen común o unas características compartidas con otra persona o grupo o con un ideal, y con el vallado natural de la solidaridad y la lealtad establecidas sobre este fundamento. En contraste con el 'naturalismo' de esta definición, el enfoque discursivo ve la identificación como una construcción, un proceso nunca terminado: siempre 'en proceso..." (Hall. 2003. Pág. 15). Intentaremos dar cuenta de las características de dicho proceso a través del tratamiento que se da a los relatos y testimonios, en los audiovisuales.

En estos convergen, interactúan y disputan imaginarios sociales que se condensan y confluyen acciones en torno a filiaciones identitarias y de diferenciación. Para ello es necesario bucear en lo profundo de la historia, los imaginarios colectivos que cargan de sentido esta parte del pasado reciente argentino ${ }^{1}$ y considerar las múltiples aristas que se entrecruzan en las audiencias, salas de sesiones, alegatos, testigos y condenas. 
Sustentamos nuestro estudio retomando los planteos de Stuart Hall, considerando que toda identidad es siempre producto de un proceso de identificación que se constituye en un momento y espacio específico, que conlleva al sujeto a inscribirse en una toma de posición, a ocupar un lugar en una red de relaciones constituida por ciertos discursos o prácticas. A partir de lo expresado, se remarca la condición posicional y relacional de la identidad que le imprime las características de inacabada, en constante cambio y reformulación. Al respecto Eduardo Restrepo (2014) nos acerca las ideas de Hall: "Esta noción posicional de la identidad permite entonces que uno hable desde ese lugar, actúe desde ese lugar, así algún día en el futuro, desde otras condiciones, uno pueda querer modificarse a sí mismo o la persona que está hablando. [...] [La identidad] Siempre está, como se dice, en proceso. Se está haciendo. Se mueve de un determinado pasado hacia el horizonte de un posible futuro que no es todavía totalmente conocido..." (Restrepo. 2014. Pág. 117).

Ello nos adentra en una de las cuestiones nodales en torno a la problemática de la identidad. Nos enfrenta a la necesidad de abordar la identidad no como algo dado que está allí y a la cual el sujeto debe adscribir, sino como el resultado de una lucha política, una lucha entendida como la articulación de experiencias y de sujetos, un proceso de construcción donde intervienen las posiciones, las ideas, el poder que conlleva al proceso de identificación.

Indagar en torno a los testimonios brindados en el marco de procesos judiciales y su incorporación a narrativas audiovisuales implica un acercamiento a las historias de vida, al mismo tiempo que, inscribirlas en las disputas políticas que atraviesan esas representaciones. En nuestro caso nos guían algunos interrogantes en torno a cómo son incorporados, utilizados los testimonios en los audiovisuales, intentando repensar el tema de la subjetivación de la experiencia, donde cada testigo, en tanto "sujeto"/actor social, es al mismo tiempo, "objeto" de indagación y búsqueda: ¿Cómo se presenta al testigo, qué función cumple su imagen y voz en el marco de la representación audiovisual? ¿Cómo se sostienen o derriban los procesos de autovictimización y/o estigmatización en los films? ¿Qué procesos de identificación o identidades de los sobrevivientes se representan o construyen en los audiovisuales sobre los juicios?

Estos interrogantes hunden sus raíces en ciertos imaginarios que se han cimentado y divulgado a lo largo del tiempo, constituidos en torno a dos visiones antagónicas difundidas socialmente: Por un lado, la idea construida y sostenida como justificativo de persecución, detención y muerte: si fueron perseguidos y detenidos es "porque algo habrán hecho... por algo será". Por otra parte, hay un imaginario colectivo que se basa en una veneración, un culto a "los muertos", especie de mártires que han logrado la redención a partir del sacrificio de dar su vida por la causa, por la revolución. Para ambas visiones el "sobreviviente" resulta una figura incomoda, para la primera resulta margen de error y fracaso en el exterminio del oponente político. Para la segunda, resulta un ser cargado de sospechas, alguien deleznable cuyas estrategias de supervivencia no quedan muy claras ni justificables. Tanto para las investigadoras Silvia Labayru como para Denise Najmanovich (2005), durante mucho tiempo se consideró a los sobrevivientes bajo la acusación más o menos velada de traición, su testimonio generalmente ha sido demandado sólo en las salas de audiencia de los tribunales donde se los ha usado y usa -cuando no abusa- de su memoria y su dolor, en tanto, fuera de esos ámbitos su voz es pocas veces requerida. En tal sentido, 
podemos diferenciar dos imaginarios sociales bien definidos en torno al detenido desaparecido, cuyas ideas y representaciones también se replican para la figura del sobreviviente. La existencia del testigo que sobrevivió a la tortura, las vejaciones, el tormento, inexorablemente nos lleva a repensar y reelaborar la historia desde una perspectiva compleja con múltiples entradas que supere visiones binarias de mártires o traidores en torno a la militancia de los ' 70 y la derrota sufrida en manos del terrorismo de Estado orquestado por las fuerzas cívico-militares que se hicieron con el poder en 1976. Según Ana Longoni “...Esos cuerpos sobrevivientes vuelven para contar y evidenciar la derrota en carne propia. Por otra parte, se construye una dualidad fuerte entre la figura del desaparecido como héroe y como mártir y su opuesto, la figura del sobreviviente como traidor. 'Si sobrevivió, algo habrá pactado, algo habrá dicho, a alguien habrá delatado', eso es lo que se escucha y se piensa resonando y duplicando, de alguna forma, en el 'por algo será' de los desaparecidos." (Longoni. 2007. Pág. 14),

En los últimos años estas ideas se están reconfigurando y trasformando, hoy encontramos más espacios donde los testimonios circulan, y es posible acceder a una problematización de la militancia, la ética y el sentido de las acciones del militante en las organizaciones políticomilitares revolucionarias. También a discursos, narrativas que escapan a la sublimación del desaparecido como "héroe", o ejemplo de militancia; En las nuevas narrativas se recupera la dimensión del sujeto enmarcado en una trama compleja de incertidumbres, deberes, anhelos, ideologías que lo llevaron a actuar según sus convicciones o posibilidades.

Focalizando en lo fílmico, en los documentales que representan los juicios por violación a los derechos humanos, el sobreviviente y su testimonio tienen un lugar preponderante. Se coloca en escena a sujetos que sobrevivieron a las torturas y violaciones e intentaron restablecer sus vínculos insertándose nuevamente al tejido social del cual fueron arrancados, pudiendo visualizar en las representaciones audiovisuales los desplazamientos en el otorgamiento de sentido a identidades múltiples, diversas y en constante cambio.

Si entendemos la identidad como aquel proceso constante, inacabado y relacional, también debemos mencionar cómo se representa al otro, al torturador, al condenado puesto en el banquillo de los acusados. En un primer momento, se alude a ellos como "fuerza", es decir, como un colectivo, no se los individualiza, sólo son sujetos que ocupan una posición en la línea de mando, son miembros o integrantes de las fuerzas armadas que cumplen con órdenes de los mandos mayores... Luego comienzan a ser individualizados, con nombre, apellido, rango dentro de las fuerzas y rol o papel en el régimen represivo en el marco del terrorismo de Estado: su grado de implicación en secuestros, torturas, desapariciones de personas, asesinatos y apropiación de bebés. Estos procesos de individualizaciones, subjetivaciones e identificaciones son posibles ante el avance y accionar de los tribunales y la justicia civil en detrimento de los argumentos militares relacionados a la obediencia debida.

Si bien nuestro objeto de indagación no está centrado en la figura de los acusados o torturadores, hacemos esta breve mención en tanto relación/ oposición al testigo sobreviviente. Para ello seguiremos los argumentos desarrollados por Eduardo Restrepo cuando afirma que "En síntesis, las identidades no son fijas ni aisladas sino posicionales y relacionales; no están definitivamente osificadas sino que están constituidas por procesos cambiantes de sedimentación e inestables suturaciones; no son totalidades cerradas y unidimensionales 
sino fragmentadas y múltiples; son histórica y discursivamente producidas a través de relaciones de poder sin garantías esencialistas. Las identidades involucran las políticas de representación y un continuo, pero nunca concluido y siempre confrontado, proceso de cerramiento y subjetivización”. (Restrepo. 2014. Pág. 117).

Con estas orientaciones teórico-conceptuales, que sustentan nuestra indagación y nos proponemos problematizar la intrincada trama de las narrativas audiovisuales y los procesos de construcción identitaria y de memoria que en ellas se construyen y representan en relación a este fragmento de nuestra historia reciente.

\section{Haciendo un poco de historia: clivajes entre políticas, imaginarios y me- morias.}

En el marco de los albores de la recuperación de la democracia y desde la campaña presidencial de Raúl Alfonsín en 1983, se aboga por la justicia y el derecho a volver a la constitucionalidad mediante el juicio y condena a los responsables de las violaciones a los derechos humanos, retomar el camino de las leyes y la Constitución Nacional, suspendidas en los años de la dictadura. Una vez en la presidencia el Dr. Alfonsín promueve el Juicio a las Juntas de Comandantes ${ }^{2}$ que dicta sentencia en 1985. Sólo a un año de los juicios se dicta la ley de Punto Final (1986) donde se establece que en 60 días se van a interrumpir las acciones legales contra los agentes de la represión. En 1987 se sanciona la ley de Obediencia Debida, consistente en que no se puede juzgar a los comandos inferiores de las fuerzas armadas de seguridad porque habían actuado en cumplimiento de órdenes provenientes de sus jerarquías. Como corolario de estas leyes, denominadas comúnmente como "leyes de impunidad o exculpatorias"3, se decretan en 1989-1990 los Indultos, mediante decretos presidenciales firmados por el Dr. Carlos Saúl Menem -presidente de la nación desde 1989-1999- se favorece a todos los integrantes de las Juntas Militares procesados y condenados en 1985 y a miembros y líderes de organizaciones político-militares revolucionarias y otras personas acusadas de subversión -entre ellos a líderes de la organización Montoneros-, se los absuelve del cumplimiento de la pena a la que habían sido condenados por vía judicial. El por entonces presidente Carlos Menem justifica la promulgación de estas leyes y decretos como estrategias que permiten "la reconciliación nacional", para poder construir una sociedad sin rencores y en paz, según expresiones del presidente de la nación, "sin reconciliación nacional no se puede gobernar".

A finales de la década del '80 la Argentina es un país sumido en la hiperinflación, que ha sufrido tres levantamientos militares (después del levantamiento de Semana Santa de 1987 conocido como "levantamiento carapintada", se sucedieron otros como el de Monte Caseros en enero de 1988, en Villa Martelli diciembre de 1988 y posteriormente, el del Regimiento I de Patricios en diciembre de 1990) y la asunción anticipada de un nuevo presidente electo, Dr. Carlos Saúl Menem, que desde su campaña electoral bregó por la pacificación de la sociedad y la reconciliación nacional, objetivos que se consolidan a través de los indultos presidenciales beneficiando a los miembros de las juntas militares juzgados 
y condenados en 1985. De esta manera el Estado comienza a desentenderse de la tarea de hacer "memoria de la represión", se impone en el imaginario colectivo la idea de la teoría de los dos demonios, con errores, horrores y excesos de ambos bandos: grupo de militares y de civiles armados en el marco de las organizaciones político-militares revolucionarias. Es a partir de 1998 en la Cámara Federal de La Plata, provincia de Buenos Aires, donde se da continuidad a las investigaciones comenzadas con el retorno de la democracia con el desarrollo de los Juicios por la Verdad, estos primeros juicios son procedimientos de investigación sin efectos penales. Con el transcurso del tiempo varios fiscales federales argentinos adoptan esta estrategia para reanudar investigaciones sobre el terrorismo de Estado; en estos procesos no se busca castigar a los culpables sino que se intenta reunir, a través de la declaración de testigos, la mayor cantidad de información posible sobre las personas desaparecidas, a fin de reconstruir cada uno de los casos.

Legalmente estas acciones de los fiscales tienen escaso sustento y su efecto práctico es nulo porque no conducen a la imputación y juzgamiento de los represores, pero las pruebas reunidas resultarán de vital importancia, más adelante en 2003, cuando las denominadas "leyes exculpatorias" son anuladas por el Congreso Nacional Argentino y dicha anulación es convalidada por la Corte Suprema de Justicia que las declara inconstitucionales en 2005. Es a partir de allí que se rehabilita la posibilidad de persecución judicial de los crímenes de Estado y en 2006 tiene lugar la primera sentencia firme tras la anulación de las denominadas "leyes de impunidad".

Con la llegada de Néstor Kirchner a la presidencia de la nación en 2003, se anuncia que su programa en relación al pasado reciente argentino se sustentará en "Memoria, Verdad y Justicia", seguido en sus dos primeras semanas de gobierno con la remoción de la cúpula de las Fuerzas Armadas y la promoción del juicio político a la "mayoría automática" de la Corte, sus objetivos eran echar luz sobre los delitos de lesa humanidad cometidos durante la dictadura cívico-militar. Se reactivan y desarrollan más de una decena de juicios por delitos de lesa humanidad a lo largo y lo ancho de todo el país, en algunos de ellos fueron juzgados civiles participantes de la dictadura. El Estado nuevamente toma en sus manos el deber de memoria a partir de políticas de memoria de diverso tipo: simbólicas, de reparación subdivididas en económicas o prestacionales y las políticas de justicia (Solís Delgadillo. 2011). En relación a ello, según diversos informes, el balance de la reapertura de los juicios por delitos de lesa humanidad es elocuente. En declaraciones a La Voz en 2014, Martín Fresneda -Secretario de Derechos Humanos de la Nación ${ }^{5}$ - expresa que “...hubo más de mil procesados y 521 condenados, consigna que hasta finales de 2012 hubo 354 condenas y 34 absoluciones, cifras demostrativas de un verdadero proceso de justicia, con respeto por las debidas garantías, de modo que nadie sea condenado sin pruebas". 6

Esta política de Estado fue sostenida hasta fines de la presidencia de Cristina Fernández de Kirchner en 2015. Se comprueba que en el 2014 al conmemorarse el 38 aniversario del golpe de Estado, se encuentra este proceso en pleno desarrollo, se hallan en marcha diversos juicios por delitos de lesa humanidad en nueve jurisdicciones (Buenos Aires, Córdoba, San Luis, Mendoza, Tucumán, Santa Fe, Paraná, entre otros) ${ }^{7}$, también en algunos de ellos comenzaron a ser juzgados civiles participantes de la dictadura, como en el juicio de 
Mendoza en el que están imputados los ex jueces Otilio Romano y Luis Miret o el caso de Santa Fe donde fue condenado Víctor Brusa por su participación siendo secretario de un juzgado federal en la ciudad de Santa Fe.

En este balance cabe consignar además la recuperación de su identidad de 116 hijos de detenidos-desaparecidos (con los últimos casos de Ignacio Hurban/ Ignacio Guido Montoya Carlotto y Jorge Castro Rubel) y el mejoramiento del sistema de búsqueda a partir del Banco Nacional de Datos Genéticos, como así también la señalización de setenta "sitios de la memoria" a lo largo y lo ancho de todo el país, con la colocación de "baldosas" señalizando lugares de secuestro, detención y desaparición de personas.

En diversas investigaciones donde se aborda el devenir de la lucha de los organismos de derechos humanos en Argentina para establecer un régimen de verdad sobre lo sucedido durante la última dictadura en el país y terminar con la impunidad de los represores, se analiza cómo diferentes instituciones y esferas estatales van apropiándose de los reclamos e imperativos sostenidos por estas organizaciones no gubernamentales y movilizaciones civiles que tienen como objetivos verdad, memoria y justicia (Alonso. 2009 y 2011). Esta tendencia se profundiza con la llegada de Néstor Kirchner a la presidencia, quien se presenta "...como representante de una generación golpeada por el terror militar y promovió diversas iniciativas para generar memorias críticas sobre la represión y las conductas mayoritarias de la sociedad argentina durante la década de 1970” (Alonso. 2011. Pág. 41), de esta manera se comienza a dar lugar a un nueva configuración imaginaria que apuntala la reactivación de la vía judicial para esclarecimiento y condena de los responsables y cómplices para/con los diferentes mandos militares.

Al mismo tiempo, la idea relacionada a la teoría de los demonios comienza a entrar en crisis dejando de ser una visión hegemónica sostenida por el Estado como política de la memoria. Según el investigador Luciano Alonso, esto puede ser leído como una tendencia de conjunto en relación al papel del Estado y los reclamos de los organismos de derechos humanos, donde convergen procesos de normalización e institucionalización de estos reclamos del movimiento argentino por los derechos humanos: “...Normalización en tanto intento de inscripción de esas demandas en la normalidad política, ajustándolas a reglas propias del Estado de derecho -lo que conllevó reiteradas tensiones al pretender el tratamiento de acontecimientos excepcionales con las tipificaciones de la legalidad republicana ordinaria. Institucionalización, porque supuso la canalización e incluso reorientación de las demandas por diversas agencias gubernamentales, asumiendo modos de relación socio-política concretos y estables garantizados por la estructura de la dominación estatal" (Alonso. 2011. Págs. 41-42).

Estas ideas nos conducen a reflexión sobre la imbricación entre política y memoria; qué estrategias o mecanismos se ponen en funcionamiento desde la sociedad y el Estado para construir memoria sobre el pasado reciente y constituir imaginarios sociales que sustentan representaciones; cómo el Estado termina cooptando manifestaciones de la sociedad civil y las hace propias en el proceso de selección y reselección del pasado como estrategias de memoria. 


\section{Las representaciones audiovisuales del juicio: proceso de identificación y subjetivación del testigo}

Una de las primeras etapas en la representación audiovisual de los sobrevivientes la podemos fijar en las producciones audiovisuales realizadas a partir de 1985 y que abordan el denominado "Juicio a las juntas" registrando lo que sucede en el tribunal y dejando prueba de la existencia real del proceso judicial, remarcando la relevancia histórica que tiene este Juicio en el contexto de posdictadura argentina. Como lo desarrollamos en páginas anteriores, las primeras sanciones judiciales a militares tuvieron lugar en 1985, luego la vía judicial se cierra con la sanción de las "leyes exculpatorias" de "Punto Final" (1986), "Obediencia Debida" (1987) y los decretos presidenciales de "Indulto" (1989/1990) a los condenados y, a partir de 1986, contamos con producciones audiovisuales que representan este proceso judicial.

El desarrollo del juicio a las juntas de comandantes en 1985 supone un hecho sin precedentes para la sociedad argentina donde convergen tres elementos que hacen que sea considerado un "juicio histórico", aún antes de comenzar (Feld, C. 2002). La Cámara Federal delineó las características que tendría el juicio: el juzgamiento a los principales responsables de una dictadura militar por violaciones a los derechos humanos; el proceso a esos militares en el ámbito de la justicia civil; la realización de un juicio oral y público. Con estos tres elementos se pretendía demostrar un distanciamiento a las posibles presiones que pudiesen darse desde el gobierno, las Fuerzas Armadas y/o el movimiento de derechos humanos, ya que las audiencias públicas se consideraban como garantía de transparencia y legitimidad del juicio ante posibles amenazas y ataques que dificultaran su desarrollo y posterior decisión del tribunal.

También se reglamentó el uso del espacio, la composición, magnitud y comportamiento del público asistente durante las audiencias, así como la difusión de las imágenes. Estas cuestiones son desarrolladas por Kaufman (1990), quien da cuenta que la sala de audiencias se había acondicionado como un gran escenario, en el que los jueces se ubicaban "por encima" de todos los demás actores intervinientes en el juicio. Esta preeminencia espacial dada a los jueces quería demostrar simbólica y espacialmente al tribunal como instancia supra-societal que dirimiría los conflictos. Se podía seguir lo que sucedía en la sala de audiencias a través de la prensa escrita y la edición especial que realizaba Editorial Perfil a través de El Diario del Juicio, una publicación semanal que informaba sobre las sesiones y publicaba las transcripciones de los testimonios ya que los periodistas acreditados no podían grabar audio, filmar o sacar fotos.

En 1986, con el aval y los medios suministrados por el gobierno de Raúl Alfonsín, se encarga al por entonces presidente de TELAM (agencia de noticias oficial), Mario Monteverde, que realice una síntesis del registro audiovisual del juicio para ser transmitido por televisión. El formato sugerido por el presidente Alfonsín es de una miniserie, con la finalidad de hacer públicas las imágenes para que todo el país y el mundo conozcan lo que había sucedido en las audiencias. Este trabajo dio como resultado a "Señores, ¡de pie!" $(1986)^{8}$ : seis videos de dos horas de duración cada uno que se dividen en casos con 
diversos títulos ("Capuchas y pañales", "La Perla", "La música del mundial”, "Viaje al Olimpo", etc.) donde se respeta en la representación la puesta en escena judicial, el objetivo es mostrar el juicio y la represión, no se presenta una explicación del sistema represivo sino pruebas/ testimonios de los crímenes de donde se deduce el funcionamiento de ese sistema. Sólo se incluyen como elemento externo al juicio en la representación los títulos y subtítulos, música de presentación y algunas fotos, sin relator ni voz en off.

Estos materiales nunca fueron proyectados ni transmitidos para ser vistos en Argentina. Momentos de incertidumbre ante los levantamientos de facciones del ejército, iniciados por el "Levantamiento Carapintada", hacen que este material no vea la luz. Los tiempos estaban cambiando y las leyes de impunidad se sancionan. Estos materiales que “...debían mostrar a toda la sociedad ese juicio visto por poca gente se transformaron en el documental que 'el país no pudo ver' ..." (Feld. 2002. Pág. 71)

Ante ello, los organismos de derechos humanos y la APDH (Asamblea Permanente por los Derechos Humanos) toman en sus manos el papel de activar el recuerdo y promover la memoria. Para ello deciden encargar a dos realizadores, Jorge Laferla y Martín Groisman: "la producción de un material más corto y accesible a la visualización a partir del material disponible en los seis cassettes del documental "Señores de Pie”. Así se produce en 1989 un documental de cuarenta minutos titulado "El juicio" (1989) 9 . En esta pieza se retoman las imágenes utilizadas por el documental antecesor, aunque el hilo narrativo, la música, el ritmo de la edición, los subtítulos le imprimen un ritmo más dinámico comprimiendo la información. Este documental respeta la idea de no incorporar elementos externos al juicio, razón por la cual no se agregan otras imágenes ni voz en off, sino que representa en el argumento textual cada uno de los hechos que se probaron en el juicio a partir de algunos testimonios emblemáticos, “...el juicio se sigue contando por sí mismo...”, en palabras de Feld (2002. Pág. 81).

Respecto a su circulación cabe destacar que se difundió en los circuitos de los organismos de derechos humanos, desde donde se proyectan en lugares que se habilitaban pero sin llegar a circuitos comerciales ni a la televisión. En la actualidad es posible acceder al mismo en el sitio de Memoria Abierta ${ }^{10}$.

A mediados de la década del `90, al acercarse los diez años de la realización del juicio a las juntas militares comienza a salir una reedición abreviada de El Diario del Juicio, en seis fascículos quincenales publicados por Editorial Perfil, estos fascículos van acompañados cada uno de un cassette de aproximadamente 30 minutos de duración con imágenes que se extrajeron de los originales guardados en la Cámara Federal, la colección se titula " $\boldsymbol{E l}$ juicio que cambió al país" (1995) ${ }^{11}$, cada entrega aborda un tema particular relacionado al pasado reciente. En estos videos se muestran los testimonios, declaraciones y alegatos del juicio respetando la idea de las imágenes del juicio como "documento", pero se agregan imágenes que contextualizan e ilustran lo que muchos testimonios van relatando. Esta estrategia le otorga cierta espectacularidad a las imágenes del juicio. Sin duda a la función conmemorativa y al "deber de memoria", se le asocia la lógica comercial del producto. En estas piezas, a nivel temático y narrativo lo central no es reconstruir lo que sucedió en el juicio, sino transmitir el horror impartido por el terrorismo de Estado. 
Entre las estrategias visuales narrativas que estructuran estos audiovisuales se destacan la apelación a las emociones y la sensibilidad del espectador. Para ello se construye una representación predominantemente expositiva, donde en cada cassette se presenta, desarrolla y concluye un tema específico, cuya voz de autoridad está dada por la argumentación del film que no tiene fisuras, no admite voces discordantes y refuerza la idea de "verdad" indiscutible e incuestionable de la representación (Nichols. 1997), aquí el juicio se enmarca como resultado deseado a una sucesión de horrores y atrocidades cometidas durante la dictadura. Por su parte, la aparición en los medios masivos de comunicación, del ex-marino Adolfo Scilingo haciendo declaraciones de cómo arrojaban personas al Río de la Plata contribuye a reabrir el debate y la necesidad de memoria a nivel de la sociedad. En este marco se comienzan a reeditar imágenes del juicio de 1985 y son exhibidas en canales de televisión de circulación masiva, dando lugar a que muchos testimonios llegaran con sonido original a la televisión abierta.

Siguiendo el derrotero histórico de estos materiales, cabe identificar que en 1998 las imágenes del juicio y sus audiencias son emitidas con su audio original por televisión, llegando a un público masivo. Por su parte, Canal 13, emite el documental "ESMA: el día del juicio" $(1998)^{12}$, realizado por una productora independiente. El film centra su argumento en un tema abordado en los juicios, lo que sucedió en la Escuela de Mecánica de la Armada (ESMA) y comienza con el relato de un joven frente al edificio de la ESMA, en su presente histórico. Con este film se trae al presente el pasado, se tiende un puente entre pasado-presente y sus secuelas, la actualidad de esos hechos y la necesidad de memoria. Varios acontecimientos daban un marco propicio para presentar este film, por un lado el presidente Menem había firmado un decreto para demoler el edificio de la ESMA y convertir el predio en un espacio verde como símbolo de "reconciliación nacional", por otra parte la agrupación HIJOS (Hijos por la Identidad y la Justicia contra el Olvido y el Silencio, creada en 1995) había crecido como organización de derechos humanos y había desplegado nuevas formas para demandar memoria y justicia. Al mismo tiempo se reactivan los juicios a militares por apropiación de menores. Claudia Feld (2002) analiza de forma exhaustiva el contrapunto que se hace en este documental entre pasado y presente, una oposición entre un pasado que debe ser narrado y un presente donde ese pasado es desconocido. El film se constituye, así como vector de transmisión de ese pasado en el presente. Con los dos últimos documentales mencionados, el juicio se enmarca en el proceso de construcción de memoria con relación al pasado reciente de manos de los medios de comunicación, logrando un alcance, circulación y audiencias hasta ese momento impensadas, con altos niveles de rating y varias emisiones/ repeticiones por canales de aire.

El documental "ESMA: el día del juicio" evidencia c una puesta en escena que plantea estrategias visuales muy diferentes a los filmes anteriores, a saber: se ingresa al juicio desde afuera. Tanto desde otro tiempo, pues es desde el presente que se bucea en el pasado; como desde afuera respecto a lo espacial, pues se ingresa desde la calle a la sala de audiencias. A su vez, se ingresa también desde fuera de los personajes directamente involucrados en la sala de audiencias. Son los jóvenes a los que se les hace una encuesta sobre "qué saben de la dictadura", la estrategia de presentación que se utiliza hasta llegar a dar con los testigos. 
Se podría arriesgar que presenciamos una intromisión de los imperativos del presente histórico y la sociedad civil en el proceso judicial, una búsqueda constante de respuestas a múltiples interrogantes que necesitan resolverse como garantía de justicia. En tal sentido, las imágenes del juicio no son utilizadas para representar el juicio en sí mismo sino para mostrar el horror y el dolor que, en ese acto judicial, se juzga y se condena. Este film se constituye en vector de memoria en términos de Henry Rousso,(2000). Revisita el pasado e instala en la agenda pública el debate en torno a la necesidad de justicia a partir de aportar a la construcción de memorias. De esta manera, en el film se construyen, discurren y se transforman las memorias. Entendiendolas como una reconstrucción actualizada del pasado que actúa en tanto estrategia de configuración y reafirmación de una identidad común y compartida.

A fines de febrero de 2004 se estrena en los cines porteños “Juicio a las Juntas. El Nüremberg argentino" $(2002)^{13}$. En este film se revisa el juicio de 1985, con la finalidad de remarcar la importancia que tuvo y tiene ese proceso judicial para el Estado de derecho y la vida democrática en el país. Se utilizan imágenes de archivo, material fílmico de la época y entrevistas actuales a seis de los principales testimoniantes, a los cuatro jueces que integraban el tribunal (los doctores León Arslanian, Ricardo Gil Lavedra, Jorge Torlasco y Andrés D'Alessio) y al fiscal Julio César Strassera, entre otros. Su director Miguel Rodríguez Arias en entrevista al diario La Nación señala: "El objetivo principal de este largometraje es dar a conocer a los más jóvenes los siniestros objetivos y métodos de la represión y proponer a los adultos un saludable ejercicio de la memoria. Al mismo tiempo, la película trata de brindar un testimonio completo de ese episodio trascendental para la historia del país y para la jurisprudencia internacional." (Montesoro en La Nación. 2004). Este documental representa a los juicios como símbolo de la búsqueda del pueblo argentino de la verdad y la justicia, considera a esta instancia judicial como "descarga" para la sociedad que contribuye a la construcción de la memoria a partir de socavar el principio de impunidad y otorgarle valor fundamental a la ley.

Como conclusión provisoria, podemos sostener que en los diferentes documentales mencionados hasta aquí hay un tratamiento del sobreviviente en tanto víctima, su testimonio es considerado prueba de la existencia del terrorismo de Estado, un plan orquestado y ejecutada desde los diferentes niveles e instituciones del Estado contra sus ciudadanos. Aquí se materializa la idea de detenido desaparecido a partir de la existencia del sobreviviente, una persona que tiene entidad con nombre y apellido, tiene existencia real; se refuerza la idea de una identidad individual, subjetiva que implica al sobreviviente como actor social que ha recuperado su entidad como un sujeto de derecho. En este sentido, se vislumbra un proceso de construcción identitaria que discurre desde ser detenido desaparecido, a víctima de torturas y tormentos, hasta llegar a ser sobreviviente y testigo en causas judiciales que buscan reparar el daño mediante el imperio de la justicia. 


\section{Otro tiempo otro lugar: los audiovisuales de juicios por delitos de lesa hu- manidad y la subjetivación de la identidad militante.}

Como pudimos observar, en la primera ola de documentales sobre el juicio a las juntas de 1985 se representa a los sobrevivientes como víctimas de torturas, vejámenes y violación a los derechos humanos, son actores sociales cuya identidad es personal, individual apela a la idea de sujeto de derecho.

Hemos relevado una segunda ola de producciones audiovisuales con la representación de los nuevos juicios que comienzan a reanudarse en diferentes juzgados federales del país, con posterioridad al 2005. Estos documentales se producen en un contexto signado por la anulación de las leyes de punto final y obediencia debida, la reanudación de los juicios por delitos de lesa humanidad en los juzgados federales de todo el país y una política de derechos humanos y memoria delineada claramente desde el Estado nacional. Como ya lo mencionamos anteriormente, a partir de 2003 las denominadas "leyes exculpatorias" son anuladas por el Congreso Nacional Argentino y dicha anulación es convalidada por la Corte Suprema de Justicia que las declaró inconstitucionales el 14 de junio de 2005. Es a partir de allí que se rehabilita la posibilidad de persecución judicial de los crímenes de Estado y cambia el orden jurídico de estos delitos, considerándose delitos de lesa humanidad.

En este segundo periodo de realizaciones audiovisuales que representan los juicios por delitos de lesa humanidad en Argentina encontramos una diversificación en la localización de los sitios de producción, que van desde el exterior a distintos puntos dentro de nuestro territorio nacional, cuestión que marca una diferencia significatica con los documentales analizados en la primera ola, cuya producción y realización se concentra en Buenos Aires. A los efectos de este trabajo focalizaremos la atención en dos series audiovisuales producidas en la provincia de Santa $\mathrm{Fe}^{15}$.

Desde el año 2003 tras la declaración de nulidad de las "leyes exculpatorias" se reabren las causas por delitos de lesa humanidad en la provincia de Santa Fe. El primer juicio que se desarrolló en la capital provincial (ciudad de Santa Fe) fue el caratulado causa "Brusa, Víctor y otros", comenzó en septiembre de 2009 y derivó en la condena de un ex juez federal, y cinco ex policías a condenas que van entre 19 y 23 años de prisión efectiva en cárceles comunes, el 22 de diciembre de 2009 el Tribunal Oral Federal de Santa Fe dio a conocer este primer fallo por delitos de lesa humanidad cometidos durante la última dictadura cívico-militar en la provincia. Al mismo tiempo, en abril del 2010 se dio a conocer la sentencia de un ex Personal Civil de Inteligencia (PCI) en el marco del segundo juicio con estas características que se tramitó en la ciudad de Santa Fe. En tanto en la ciudad de Rosario (Santa Fe), también en abril del 2010 se condena a prisión perpetua a miembros de las fuerzas armadas y agentes civiles que colaboraron con ellos en el marco del territorio provincial durante la última dictadura, convirtiéndose en el primer fallo en la ciudad de Rosario por estos delitos ${ }^{16}$.

A partir del año 2009 a la fecha han tenido sentencia firme varias causas por delitos de lesa humanidad en el marco del territorio santafesino, al mismo tiempo el gobierno provincial ha instrumentado una serie de políticas públicas destinadas a acompañar a la justicia. En esta investigación nos interesa remarcar la decisión del gobierno de la provincia de Santa Fe de convocar a documentalistas, realizadores, colectivos de realizadores para producir 
materiales audiovisuales a partir del material que surgía de estos procesos judiciales y su transcendencia, ya que se están juzgando y condenando delitos imprescriptibles cometidos en el marco del terrorismo de Estado a lo largo y a lo ancho de todo el territorio nacional. En tal sentido, se desarrollaron políticas culturales y de memoria delineadas y sostenidas por el Estado provincial desde el Ministerio de Innovación y Cultura de la Provincia de Santa Fe al encomendar la tarea a cineastas y documentalistas para realizar el registro y la producción de films documentales que representan las diferentes etapas, laberintos y complejidades afrontadas en los juicios orales y públicos a represores acusados por delitos de lesa humanidad perpetrados durante la última dictadura cívico-militar en el país.

Este emprendimiento cultural para producir audiovisuales sobre los juicios en Santa Fe se imbrica con políticas públicas de la memoria sostenidas por el Estado nacional y provincial en relación a la historia reciente, nos permiten adentrarnos en la problemática de la representación, centrando la atención en la representación fílmica documental en tanto estrategia de preservación, salvataje, divulgación y conocimiento del pasado.

Las producciones audiovisuales realizadas en la provincia de Santa Fe se organizan en una serie de capítulos para televisión (mediometrajes), aunque a los efectos de este trabajo analizaremos cada producción en su totalidad y no nos detendremos en las particularidades de cada capítulo de ambas series. Sino que nos centraremos en los documentales en el marco de políticas de memoria y la representación que construyen del sobreviviente en sus narrativas audiovisuales a partir de rescatar la voz de los testigos sobrevivientes.

La primera serie de documentales analizada, Los días del juicio (2010 $)^{17}$, exhibe las imágenes de la sala de audiencias, el relato de los testigos y el trabajo de jueces, abogados y fiscales. Al mismo tiempo que refleja el acompañamiento que los familiares y sobrevivientes hicieron durante todo el juicio en la puerta del Tribunal.

La segunda serie titulada Proyecciones de la memoria $(2011)^{18}$, nos acerca imágenes y testimonios de la llamada "Causa Brusa" que -después de más de treinta años de espera- se llevó a juicio y se logró sentenciar a los imputados al demostrarse la ilegalidad de los actos cometidos en el marco de un plan sistemático y generalizado de represión por parte del Estado en la ciudad de Santa Fe y zonas aledañas. Además de registrar la historia de cinco mujeres que luego de treinta años lograron cerrar un ciclo de impunidad con una condena que marca una nueva etapa en materia de memoria, verdad y justicia en la sociedad santafesina.

Nos interesa indagar en estas representaciones audiovisuales donde constatamos un corrimiento en torno a los procesos de identificación de los detenidos desaparecidos sobrevivientes, hoy testigos en los juicios. Para ello reponemos la voz y las ideas de los sobrevivientes que circulan y se registran en las series de documentales seleccionadas para el análisis.

A nivel temático, ambas series de documentales, traen al presente el rol de la militancia, la posibilidad de considerar a los detenidos desaparecidos como militantes de diferentes partidos políticos, agrupaciones y organizaciones sindicales con claros posicionamientos político-ideológicos: "Yo decía: alguna vez trátenme como una presa política, en cuanto a discusión política, en cuanto al trato... no viste... era todo el manoseo, el menosprecio..." (expresiones de Anatilde Bugna querellante en Proyecciones de la Memoria, capítulo $\mathrm{N}^{\circ} 1$ ). El tema, soslayado o minimizado en gran parte de las representaciones anteriores que se limita a representarlos como "mártires" carentes de deseos, acciones y decisiones, se revierte en este contexto. 
En estas narrativas se reconoce el lugar del militante, se les devuelve las ideologías e ideas por las que lucharon. A nivel de la puesta en escena cabe señalar que los sobrevivientes "aparecen", se les otorga rostro en el preciso instante en que los sobrevivientes pueden ofrecer testimonios frente al tribunal y las cámaras captan sus rasgos, gestos, expresiones, silencios, cavilaciones. "Nuestros testimonios serán ofrecidos a la justicia sin vendas ni capuchas, por nuestra memoria viva y de frente al futuro, por la verdad, por nuestros hijos, por nuestros 30.000 compañeros desaparecidos... en democracia sano juicio..." (expresiones de Silvia Abdolatif querellante en Proyecciones de la Memoria, capítulo $\mathrm{N}^{\circ} 1$ ).

En las representaciones fílmicas también se aborda la manipulación y manejo de información que llevaron adelante los mandos militares en connivencia con agentes civiles para justificar el secuestro y privación ilegal de la libertad de personas identificadas como militantes en diferentes organizaciones político-militares revolucionarias. Al mismo tiempo, se desmantela la idea que los mandos militares buscaron construir e impartir alrededor del sobreviviente como "traidor". Estrategia sostenida en la creación de un manto de sospechas sobre la delación de sus compañeros en torno a la figura del sobrevivientes a los centros clandestinos de detención; maniobra que buscaba deslegitimar las vivencias, la palabra y los testimonios de los detenidos desaparecidos sobrevivientes.

Esto lo podemos constatar en la narrativa audiovisual cuando se presentan las declaraciones ante el tribunal de Eduardo Rodolfo Constanzo, civil acusado de participar en secuestros y torturas de detenidos desaparecidos de forma ilegal junto a los militares. Accedemos a su testimonio como imputado, quien declara: “...en la Quinta de Funes estaba la cúpula guerrillera, la cúpula de Montoneros y allí la pasaron muy bien, eran catorce personas, donde se jugaba a la pelota, se bañaban en la pileta, comían asado todos los días, era como una casa quinta..." (expresiones de Eduardo Rodolfo Constanzo acusado en Los días del juicio, capítulo $\mathrm{N}^{\circ} 3$ ). Es necesario remarcar que la Quinta de Funes fue uno de los principales centros clandestinos de detención de la ciudad de Rosario, allí se orquestó un plan para quebrar psíquica y emocionalmente a los detenidos, sólo hay un sobreviviente que estuvo secuestrado allí que puedo escapar ante un intento de los militares de infiltrar a los detenidos en un grupo de dirigentes de la organización Montoneros que se encontraba exiliada en México en 1978. Un periodista de Rosario/12 relata en el marco del audiovisual que “...hay una persona cuyo testimonio es fundamental al respecto, que es el de Jaime Dri. Es el único sobreviviente conocido de la Quinta de Funes, pudo escapar y está viviendo en Panamá... se fugó en la 'operación México' donde un grupo de detenidos viaja con algunos militares, entre ellos Amelong a México para tratar de asesinar a líderes Montoneros que estaban en México. La Quinta de Funes fue una experiencia que fracasa con el operativo en México porque Dri, apenas llegan allí, denuncia a la prensa los planes de los militares..." (expresiones del periodista José Maggi en "Los días del juicio", capítulo №3).

En el caso de los victimarios, son presentados como "acusados" con la posibilidad de negarse a declarar y con derecho a defensa en el transcurso de las audiencias del juicio, en palabras de Daniela Asinari abogada: “...llevamos adelante el reclamo de ustedes por juicio y castigo... estamos seguros que serán condenados pero hay que 'aguantar el derecho a defensa', si no se respeta el derecho a defensa no hay juicio, estos tipos van a tener una condena ejemplar basada en un Estado de derecho y esto es lo que nos separa del accionar 
de 'esas bestias' ..." (expresiones de Daniela Asinari abogada querellante en "Los días del juicio", capítulo $\mathrm{N}^{\circ} 2$ ).

En estos films se representa a los sobrevivientes en tanto sujetos que han sufrido torturas, vejaciones, violaciones y atropello de sus derechos, pero no se hace hincapié en ello, sino que a nivel narrativo y de la puesta en escena se presenta a estos sujetos como querellantes que luchan por el reconocimiento de sus derechos en el marco de instancias judiciales garantizadas por un Estado de Derecho; “... en estos últimos días víctimas, sobrevivientes, compañeros y compañeras queridos estuvimos en un mismo recinto con nuestros torturadores. Entiéndase por tortura no sólo la física sino también la vejación continua, diaria durante años que sufrimos nosotros y cada uno de nuestros familiares. Más allá de cualquier análisis, deseamos que quede escrito y claro, totalmente claro, que siguen mintiendo, su arrogancia, sus miradas, sus gestos nos paralizó en el tiempo... Les garantizamos a todos el derecho a un sano juicio, les garantizamos el derecho a la defensa, les garantizamos lo justo y necesario. No nos vencieron, podemos ofrecer justicia sin rencor ni odio porque no olvidamos que formamos parte de una juventud que quiso cambiar el mundo para lograr una sociedad más justa, más solidaria, más igualitaria..." (expresiones de Silvia Abdolatif querellante en Proyecciones de la Memoria, capítulo $\mathrm{N}^{\circ} 1$ ). Hacia el final del film, Silvia Abdalatif lee estas líneas mientras la cámara registra en plano detalle expresiones de su rostro y el movimiento de sus labios mientras transcurre la lectura, se intercalan y superponen estos planos detalles con imágenes del juicio donde brindó testimonio como testigo sobreviviente. Se representa una superposición de imágenes, rostros, espacios, luces y sombras que convergen en la sala del juzgado como espacio de redención y justicia. Una característica novedosa y significativa es que se exhibe una nueva forma de identificar y nombrar a los sujetos, que los aleja de la representación plana de víctimas y los presenta como sujetos portadores de derecho. En estas piezas documentales se instituyen como "querellantes" en causas donde se investiga y juzga delitos de lesa humanidad.

En estas representaciones audiovisuales se transita el proceso de construcción identitaria de los sobrevivientes como querellantes y testigos, personas que han continuado su vida basada en la militancia y la lucha por justicia y la reconstrucción histórica de lo vivido, atravesados por múltiples dimensiones que los cruzan como sujetos, en tanto militantes de ayer y de hoy; con vidas rotas pero que se han podido reconstituir, regenerar a partir de la memoria y la justicia. Algunas palabras de Ramón Verón expresan estas ideas: “...y bueno yo me mentalicé que a mis 53 años mi vida va terminar un poco así paralela, criando a mi hija y paralela a toda esta historia ... yendo a testificar a Córdoba en la causa de "La Perla" porque la causa de Hilda (hace referencia a Hilda Cardozo su compañera desaparecida en 1978) quedó allá, que es el último lugar donde la vieron con vida..." (expresiones de Ramón Verón querellante en Los días del juicio, capítulo $\mathrm{N}^{\circ} 2$ ).

A partir de los procesos de identificación de los sobrevivientes que se construyen en y desde los documentales, podemos retomar las ideas de Hall en cuanto al uso que hace del término identidad “...para referirme al punto de encuentro, el punto de sutura entre, por un lado, los discursos y prácticas que intentan «interpelarnos», hablarnos oponernos en nuestro lugar como sujetos sociales de discursos particulares y, por otro, los procesos que producen subjetividades, que nos construyen como sujetos susceptibles de «decirse». De 
tal modo, las identidades son puntos de adhesión temporaria a las posiciones subjetivas que nos construyen las prácticas discursivas" (Hall. 2003. Pág. 20).

También podemos visualizar, que en estos films se da lugar a un actor inexistente o poco representado en los anteriores registros documentales: los hijos en tanto militantes en el presente.

Se reactualiza el rol de la militancia en la representación de la figura de los hijos de los detenidos desaparecidos, aquellos bebes y niños expropiados por los militares y sus cómplices como si fuesen una especie de "trofeo" o "botín de guerra". En Los días del juicio, con el caso de Sabrina Gulino entra en escena el reclamo de la agrupación HIJOS que desde su conformación en 1995 lucha por los derechos humanos, la verdad y la justicia, una lucha y una militancia donde el juicio y castigo a los culpables del terrorismo de Estado, tanto civiles como militares ocupó y ocupa un lugar central. Pasado-presente y futuro, tres temporalidades hilvanadas por un mismo imperativo, la necesidad y la concreción de justicia. El testimonio de Sabrina Gulino ante el tribunal personifica la interrelación de estas tres temporalidades, explica: “...viví la mayor parte de mi vida sabiendo que era adoptada pero no sospechaba que era hija de desaparecidos ya que con mis padres adoptivos siempre tuvimos una muy buena relación, cuando me citaron a declarar junto a mis padres y me hice el ADN y dio positivo con el grupo familiar Valenzuela-Negro lo primero que pensé fue 'hace tanto que me están buscando' y sentí la necesidad de ver fotos, de encontrar parecidos. Cuando mi madre adoptiva vio las fotos me dijo, 'sos igual a tu mamá' y esas son expresiones que en la vida no te las vas a olvidar... le pido al tribunal que por favor aparezca mi hermano mellizo, esas personas que están ahí sentadas además de todas las responsabilidades que tienen, son los responsables de que nuestro hermano se encuentre desaparecido..." (expresiones de Sabrina Gulino querellante en Los días del juicio, capítulo $\mathrm{N}^{\circ} 4$ ).

Ambas serie de audiovisuales santafesinos no se cierran en sí mismos, sino que poseen una estructura dinámica que los coloca en relación/ tensión constante entre los acontecimientos representados, juzgamiento a responsables de violaciones sistemática a los derechos de otros individuos en el pasado, pero cuyas consecuencias están vigentes en nuestro presente histórico ya que individual y socialmente todavía se desconoce el paradero de muchos detenidos desaparecidos, y la localización, identificación y restitución de identidad a niños (hoy adultos) nacidos en cautiverio y apropiados por los militares y sus cómplices. "El juicio le dio visibilidad a lo que ocurrió durante la dictadura y eso fue... tiene un valor histórico muy importante..." (expresiones de Stella Maris Vallejo querellante en Proyecciones de la Memoria, capítulo $\mathrm{N}^{\circ} 1$ ).

Estas realizaciones audiovisuales nos proponen una relectura del pasado más compleja, ya que han podido unir a todos los actores implicados en esta trama histórica: sobrevivientes, hijos, militantes de derechos humanos, ciudadanos voluntarios en las causas, abogados, jueces, incluso a los acusados, perpetradores de la violencia y la suspensión de los derechos y garantías constitucionales.

En ambas series de documentales se profundiza sobre los procesos de enjuiciamiento por delitos de lesa humanidad y se apela a la representación de una identidad colectiva, mostrando al sujeto interpelado por múltiples identidades en tanto actor social, militante, 
obrero, estudiante, intelectual, padre, madre, hijo... No se abandona la idea de sujeto de derecho, pero visibilizan los procesos de identificación de esos sujetos con ideas, ideologías y posicionamientos políticos específicos devolviéndoles el estatus de actor social implicado en la realidad que les toca vivir.

\section{A modo de cierre}

En este trabajo consideramos necesario realizar el análisis de los audiovisuales que representan los juicios por violación a los derechos humanos durante la última dictadura cívico-militar en Argentina en sus contextos de producción. Ello nos permite identificar diferentes cortes temporales dentro del caso argentino a partir de las disputas políticas y de poder, donde las políticas de justicia y de memoria tienen características específicas como resultado de luchas concretas desatadas sobre los sentidos otorgados al pasado.

$\mathrm{Al}$ abordar los diferentes contextos de producción y sus temporalidades, podemos diferenciar etapas o recortes temporales a partir de los cuales se va dando el corrimiento de representaciones diversas en torno a la identidad, accediendo a los procesos de construcción de identidades que luego cristalizan en las representaciones audiovisuales. Representaciones y prácticas presentes en el imaginario social que contribuyen a los procesos de configuración identitaria que nutren las representaciones documentales que se constituyen en un círculo virtuoso en el proceso de construcción y delimitación de identidades y memorias en torno a un grupo de semejantes que se alejan y diferencian de un otro... Ante lo expuesto, podemos afirmar que en los films realizados en función del juicio a las juntas militares de 1985, el proceso de enjuiciamiento es representado por sí mismo, con materiales producidos en las salas de audiencia a partir de testimonios de testigos, detenidos desaparecidos sobrevivientes a las torturas, familiares de víctimas, alegatos de fiscales, abogados querellantes y abogados defensores, declaraciones de los acusados imputados.

La cámara se presenta como un lente que nos acerca lo que sucede en el ámbito de la justicia, como fiel testigo de lo que allí está aconteciendo, al mismo tiempo que preserva el registro como prueba y garantía de que este proceso judicial existió.

Los sobrevivientes son representados como víctimas que ofician de querellantes en el marco de procesos judiciales donde se persigue la condena de hechos delictivos. Son sujetos identificados con nombre y apellido que han sufrido diversos grados de tormentos y torturas.

Esta representación corresponde a un primer momento en el que el gobierno en representación del Estado nacional toma un papel activo en relación a la justicia y la memoria. Por un lado, promoviendo los juicios como instancias de "reparación" donde imperase el Estado de derecho y una institucionalidad democrática, donde la verdad y la justicia son líneas rectoras en el proceso de reconstrucción de la historia y, por otro, impulsando la realización de los films que den visibilidad a lo que acontece en la sala de audiencias, promoviendo la construcción de la memoria centrada en la necesidad de condena y justicia como garantía de la democracia. 
A comienzos de la década del '90 el escenario político y económico ha cambiado, la principal preocupación del gobierno es lograr estabilidad económica para sustentar las bases de un modelo neoliberal y acallar el descontento de diferentes sectores del ejército, cuestiones que se vienen trabajando a partir de las sanciones de las leyes de impunidad. Ante este panorama, los organismos de derechos humanos y la APDH son los encargados de sostener y reactivar la memoria en torno al pasado reciente.

A mediados de la década de los `90, ante el inminente aniversario de los 30 años del golpe militar, la temática de la dictadura cívico-militar y el juicio a los culpables vuelva a estar en la agenda pública. Esta cuestión interesa a Editorial Perfil (empresa editorial argentina especializada en la producción de materiales y revistas semanales) que decide reeditar una versión reducida de los materiales escritos y audiovisuales producidos durante el juicio de 1985 convirtiéndolo en un producto mediático y de amplia comercialización. A su vez, una productora independiente donde participa Magdalena Ruiz Guiñazú (periodista argentina que integró la CONADEP y se la asocia con la defensa de los derechos humanos) retoma la temática de los hijos nacidos en cautiverio relacionando las atrocidades del pasado con los sufrimientos del presente en una nueva generación de argentinos.

Por lo tanto, nos encontramos con una reedición de la temática y el impacto que tiene en las audiencias y públicos de los medios de comunicación masivos en el país, hacen que el tema se vuelva comercialmente atrayente. A fines de la década de los '90 el deber de memoria ya no lo ejerce el Estado sino que es sostenido por los organismos de derechos humanos y los medios de comunicación, cada uno persiguiendo objetivos diferentes pero aportando a la construcción de la memoria en torno al pasado reciente.

Hacia mediados del 2000, luego de la anulación de las leyes de impunidad y la rehabilitación de los juicios por delitos de lesa humanidad, podemos acceder a múltiples registros audiovisuales que representan estos juicios a lo largo y a lo ancho de todo el país. Focalizamos nuestra indagación en dos series documentales producidos en la provincia de Santa Fe que nos acercan tópicos o aristas de la temática que no fueron abordadas por los documentales realizados en etapas anteriores.

En estos documentales que representan los juicios por delitos de lesa humanidad se restituye la dimensión de militante al sobreviviente, testigo y querellante en los juicios. Se representa el proceso de identificación de estos sujetos adscriptos a ideas político-ideológicas que sustentan sus acciones y prácticas del pasado y del presente. Al mismo tiempo, se trabaja la representación de los hijos de los detenidos desaparecidos y el rol militante en pos de la justicia, la verdad y la memoria.

Estamos en condiciones de afirmar, que los documentales que representan los juicios por violación a los derechos humanos durante la última dictadura cívico-miliar en Argentina -analizados a lo largo de este escrito- son vector de memoria en tanto y en cuanto revisitan y resignifican este tramo del pasado reciente.

En dichos audiovisuales se construyen procesos de identificación de los sobrevivientes que se constituyen como testigos y querellantes, sujetos de carne y hueso que han sufrido torturas y tormentos en detenciones ilegales. Podemos observar en los films más recientes como se da un corrimiento en la representación identitaria de los sobrevivientes, que no 
dejan de ser testigos calificados cuyos testimonios son primordiales en los procesos de enjuiciamiento, pero en estas narrativas audiovisuales la centralidad está en devolverles las ideas, intencionalidades y militancia política que los constituye como sujetos, como actores sociales de ayer y de hoy que disputan espacios de poder y tienen participación en luchas políticas de su tiempo.

\section{Bibliografía}

Alonso, L. (2009). “Memorias sociales y Estado en Santa Fe, Argentina, 2003-2008”, en revista Política y Cultura No 31, México. Universidad Autónoma de México. Disponible en: https://www.redalyc.org/articulo.oa?id=26711982003 Fecha de última consultado el 20 de febrero de 2021

Alonso, L. (2011). "Vaivenes y tensiones en la institucionalización de las memorias sobre el terror de Estado. El caso de Santa Fe, Argentina, entre 1983 y la actualidad" en Cuadernos de Historia, Serie Economía y Sociedad, N² 12, CIFFyH-UNC, Córdoba.

Campo, J. (2011). "El actor militar y el cine documental argentino (60 y ` 80). Antagonismos y radicalidad. En Revista Culturas. Debates y perspectivas de un mundo en cambio. Santa Fe. Ediciones UNL

Campo, J. (2017). Revolución y democracia. El cine documental argentino del exilio (19761984). Ediciones CICCUS- Cine Documental. Buenos Aires.

Casale, M. (2011). "El cine en la posdictadura: los documentales histórico-políticos durante el primer gobierno democrático". En, Lusnich, Ana Laura y Piedras, Pablo, Una historia del cine político y social en Argentina. Formas, estilos y registros. Volumen II (1969-2009). Editorial Nueva Librería, Buenos Aires.

Elster, J. (2006). Rendición de cuentas. La justicia transicional en perspectiva histórica. Buenos Aires. Katz Editores.

Feld, C. (2002). Del estrado a la pantalla: las imágenes del juicio a los ex comandantes en Argentina. Madrid, España. Siglo XXI Editores.

Hall, S. (1996). “¿Quién necesita identidad?” En Hall, S y Du Gay, P. (ed) (2003) Cuestiones de identidad cultural. Buenos Aires: Amorrortu Editores.

Kaufman, E. (1990). "El ritual jurídico en el juicio a los ex comandantes. La desnaturalización de lo cotidiano”. En, Rosana Guber (comp.) El Salvaje metropolitano. Buenos Aires. Editorial Legasa.

Labayru, S. y Najmanovich, D. (2005). "Sobre/vivir a la víctima”. Disponible en http://www. denisenajmanovich.com.ar Fecha de última consultado el 14 de febrero de 2016.

Labayru, S. y Najmanovich, D. (2007). "Subjetividad, ética y política. ¡CONTRA FRANCO, ÉRAMOS MÁS JOVENES!", en Revista “Campo Grupal” N 88, Buenos Aires. Disponible en http://www.denisenajmanovich.com.ar Fecha de última consultado el 14 de febrero de 2016.

Longoni, A. (2007).Traiciones. La figura del traidor en los relatos acerca de los sobrevivientes de la represión. Buenos Aires: Grupo Norma. 
Nichols, B. (1997). La Representación de la Realidad. Cuestiones y conceptos sobre el documental. España. Paidós.

Nichols, B. (2013). Introducción al documental. México. Universidad Nacional Autónoma de México.

Nino, C. (2015. Edición ampliada). Juicio al mal absoluto. ¿Hasta dónde debe llegar la justicia retroactiva en casos de violaciones masivas de los derechos humanos?. Argentina. Siglo XXI editores.

Oberti, A. y Pittaluga, R. (2001). “¿Qué memorias para qué políticas?”. En El Rodaballo. Revista de política y cultura, No 13, Buenos Aires.

Ortiz, R. (1998). Mundialización y cultura. Buenos Aires: Alianza Editorial.

Restrepo, E. (2014). "Sujeto e identidad”, en Stuart Hall desde el Sur: legados y apropiaciones. Buenos Aires: CLACSO.

Rousso, H. (2000). "El duelo es imposible y necesario" entrevista a H. Rousso por Claudia Feld en revista Puentes, año $1 \mathrm{~N}^{\circ} 2$. Diciembre del 2000.

Sala, J. (2011). “La experimentación radical y las nuevas fronteras de la política en el cine de la posdictadura”. En, Lusnich, Ana Laura y Piedras, Pablo, Una historia del cine político y social en Argentina. Formas, estilos y registros. Volumen II (1969-2009). Editorial Nueva Librería, Buenos Aires.

Selser, C. (1998) "El juicio que nunca se vio". En, Clarín suplemento "Zona”. 6 de septiembre. Buenos Aires.

Solís Delgadillo, J. M. (2011). “Políticas públicas y políticas de la memoria en Argentina y Chile: agendas y toma de decisiones". Instituto de Iberoamérica (Universidad de Salamanca). Disponible en: http://www.derhuman.jus.gov.ar/conti/2011/10/mesa_29/ solis_delgadillo_mesa_29.pdf Fecha de última consultado el 14 de febrero de 2021.

Solis Delgadillo, J. M. (2012). "El peso político del pasado: factores que inciden en la formulación de las políticas de la memoria en Argentina y Chile”. En, América Latina Hoy $\mathrm{N}^{\circ} 61$. Ediciones Universidad de Salamanca. Disponible en: https://dialnet.unirioja.es/ servlet/articulo? codigo=4017112 Fecha de última consultado el 10 de febrero de 2021 .

Vega, N. (2016). De la militancia estudiantil a la lucha armada. Radicalización del estudiantado universitario santafesino en la segunda mitad de la década de 1960. Tesis doctoral. Universidad Nacional de Entre Ríos (UNER). Banco de tesis, Red Interdisciplinaria de Estudios sobre Historia Reciente. Disponible en https://www.riehr.com.ar/index.php Fecha de última consulta 20 de marzo de 2021

Wortman, A. (1996). "Repensando las políticas culturales de la transición". En, Revisa Sociedad $N^{\circ}$ 9. Cultura, entre la permanencia y el cambio. Facultad de Ciencias Sociales-UBA.

Zylberman, L. (2015). "Imágenes de Justicia” en Revista Telar. Edición del Instituto Interdisciplinario de Estudios Latinoamericanos de la Universidad Nacional de Tucumán. San Miguel de Tucumán.

Zylberman, L. (Editor). (2012). Dossier "Memoria y Cine Documental en América Latina", en Revista Cine Documental N ${ }^{\circ}$. Consultad en http://revista.cinedocumental.com.ar/5/ articulos.html Fecha de última consulta 20 de marzo de 2021 


\section{Notas:}

1. Desde la historia cuando utilizamos la expresión "pasado reciente argentino", es para dar cuenta del periodo de tiempo transcurrido entre los años 1976-1983, más concretamente a lo acontecido durante la última dictadura cívico-militar en Argentina cuando las Fuerzas Armadas toman el poder por la fuerza y llevan adelante un plan sistemático de desaparición forzada de personas basado en las detenciones ilegales, las torturas, las vejaciones, la apropiación de niños, la muerte y/o desaparición de todos aquellos individuos que se consideraban un obstáculo al modelo económico y político que se quería implantar. Estas acciones se califican de terrorismo de Estado ya que se corroboró la existencia, planificación y desarrollo de un plan sistemático para desaparecer y eliminar a toda persona que se considerase como opositor a las políticas impuestas.

2. Nombre con el que se denomina y conoce comúnmente al proceso judicial realizado por la justicia civil (en oposición a la justicia militar) en la Argentina en 1985 contra las juntas militares que ocuparon el poder del Estado entre 1976-1983 por las graves y masivas violaciones de los derechos humanos en ese periodo.

3. Las denominadas "leyes de impunidad o exculpatorias" son: La Ley No 23.492 de Punto Final, es una ley argentina que estableció la caducidad de la acción penal (prescripción) contra los imputados como autores penales responsables de haber cometido el delito complejo de desaparición forzada de personas (que involucró detenciones ilegales, torturas y homicidios agravados o asesinatos) que tuvieron lugar durante la dictadura cívico-militar que no hubieran sido llamados a declarar "antes de los sesenta días corridos a partir de la fecha de promulgación de la presente ley" promulgada el 24 de diciembre de 1986. La Ley No 23.521de Obediencia Debida, es una disposición legal dictada en Argentina en junio de 1987, que estableció una presunción (es decir, que no admitía prueba en contrario, aunque si habilitaba un recurso de apelación a la Corte Suprema respecto a los alcances de la ley) de que los delitos cometidos por los miembros de las Fuerzas Armadas cuyo grado estuviera por debajo de coronel (en tanto y en cuanto no se hubiesen apropiado de menores y/o de inmuebles de desaparecidos), durante el terrorismo de Estado y la dictadura militar no eran punibles, por haber actuado en virtud de la denominada "obediencia debida" (concepto militar según el cual los subordinados se limitan a obedecer las órdenes emanadas de sus superiores). Se conoce como los indultos a una serie de decretos sancionados en octubre de 1989 y diciembre de 1990 por el entonces presidente de Argentina, Carlos Saúl Menem, conmutando penas a civiles y militares que cometieron delitos durante la dictadura, incluyendo a los miembros de las juntas militares condenados en el Juicio a las Juntas de 1985.

4. Expresiones del presidente de la nación Argentina entre 1989 a 1999, Dr. Carlos Saúl Menem en diferentes oportunidades como justificativo de los indultos mediante decretos presidenciales.

5. Martín Fresnada es abogado, fundador y militante de la agrupación HIJOS Regional Córdoba, fue designado por Cristina Fernández de Kirchner y se desempeñó como Secretario de Derechos Humanos de la Nación entre 2012 y 2015. 
6. Serafini, Horacio. "Derechos Humanos: luces y sombras de la política kirchnerista" en La Voz, 23/03/2014 disponible en http://www.lavoz.com.ar/politica/derechos-humanosluces-y-sombras-de-la-politica-kirchnerista Consultado el 16 de Diciembre de 2014.

7. Para mayor información de las causas vigentes en desarrollo en el 2015 http://www.telam.com.ar/notas/201503/98885-a-39-anos-del-golpe-civico-militar-se-realizan-13-juicios-por-delitos-de-lesa-humanidad.html Consultado el 15 de Marzo de 2015; Para conocer datos actualizados a marzo de 2020 sobre los juicios https://www.fiscales.gob.ar/ lesa-humanidad/24-de-marzo-la-procuraduria-de-crimenes-contra-la-humanidad-actualizo-los-datos-sobre-el-proceso-de-juzgamiento/ Consultado el 15 de marzo de 2021.

8. Seis videos documentales de dos horas de duración cada uno. Dirección: Mario Monteverde. Guion: Carlos Somigliana. Edición: Mariana Taboada. Producción periodística: Claudia Selser, 1986. Buenos Aires.

9. Documental, 40 minutos. Guion: Martín Groisman y Jorge Laferla, 1989. Buenos Aires. 10. Se puede consultar el sitio http://www.memoriaabierta.org.ar/wp/

11. Seis videos documentales de una duración de 30 minutos cada uno. Editorial Perfil, 1995. Buenos Aires.

12. Documental, 47 min. Producción: Magdalena Ruíz Guiñazú. Idea: Rolando Graña y Walter Goobar. Edición: Silvia Di Florio, 1998. Buenos Aires.

13. Documental, 83 minutos. Dirección: Miguel Rodríguez Arias; Guión: Fredy Torres y Miguel Rodríguez Arias, 2002. Buenos Aires.

14. Montesoro, Julia. "El Nüremberg argentino" nota escrita en La Nación, sección Espectáculos. 25 de febrero 2004.

15. Además de los audiovisuales analizados en este trabajo, se han producidos diversos documentales que representan juicios por delitos de lesa humanidad en Argentina. Como ejemplos podemos mencionar a: "Un claro día de justicia"(Documental. 52 minutos. Dirección Ingrid Jaschek; Ana Cacopardo- 2006. Buenos Aires); "Nosotras que todavía estamos vivas" (Documental. 85 minutos. Director: Daniele Cini, 2009. Coproducción Argentina-Italia); "Imprescriptible"(Documental. 103 minutos. Dirección: Alejandro Ester, 2013. Buenos Aires); "La sentencia: crónica de un día de justicia" (Documental. 72 minutos. Guillermo Iparraguirre-coordinador del Cepic, 2018. Córdoba), entre otros.

16. Para conocer los diferentes juicios por delitos de lesa humanidad que se tramitan en el territorio de la provincia de Santa Fe se puede acceder a https://www.santafe.gov.ar/ index.php/web/content/view/full/137056/(subtema)/93806 Fecha de última consulta 20 de marzo de 2021.

17. Serie documental de cuatro capítulos de 50 minutos. Dirección: Pablo Romano, 2010. Rosario.

18. Serie documental de tres capítulos de 50 minutos. Dirección: Betania Cappatto, Patricio Agusti y Gonzalo Gatto, 2011. Santa Fe. 


\begin{abstract}
Abstrac: The objective of this work is taking a route over the image of the "survivor" which is constructed on documentary films that represent the trials for violation of human rights during the last civic-military dictatorship in Argentina. Since the middle of the 80's to this day we can see displacements on the image represented on audiovisuals around the survivor. This is attach with collective processes of identification, where the "other" works as a referential frame, allowing the subjects legitimize themselves in the same opposition from differentiation.

On a first moment, survivors have a name but no a face, on the trials to the boards (1985) they are witnesses back to the camera, with an identity ascription associated to the personal identity which shows them as victims of different tortures and harassment, devoid of interests, compromises and fights. With time pass political affiliation is restored to the disappeared detainees, they are approached as subjects framed on ideological fights and social interactions, by this way the identity of the subject become more complex, it is approached as a contextualized social actor.

The audiovisual documentaries corpus that represent the trials for human rights violation during the last civic-military dictatorship in Argentina it's constituted by: "Señores, ide pie!" (1986); "El juicio" (1989); "El juicio que cambió al país" (1995); "ESMA: el día del juicio" (1998); "Juicio a las Juntas. El Nüremberg argentino" (2002); "Los días del juicio" (2010); "Proyecciones de la memoria" (2011).

This article will investigate the construction of survivor's identity, from the analysis reflection of these audiovisual registers, addressing as a collective subject, understanding that the reflection around the survivors is necessary as a task towards to the past but also to the present of the human rights, the justice and the memory.
\end{abstract}

Keywords: identity - survivor - documentaries - representation - trials.

Resumo: O objetivo deste trabalho é fazer um recorrido sobre a imagem do "sobrevivente" que se constrói em documentários que representam os julgamentos por violações dos direitos humanos durante a última ditadura cívico-militar na Argentina. De meados da década de 1980 até os dias atuais, podemos ver mudanças na imagem que é representada nos audiovisuais em torno ao sobrevivente. Esta está ligada a processos de identificação coletiva, onde o "outro" funciona como quadro referencial que permite aos sujeitos legitimarem-se na mesma oposição, a partir da diferenciação.

Num primeiro momento, os sobreviventes têm nome mais não rosto, no julgamento das diretorias (1985) são testemunhas de costas para a câmera, com uma atribuição de identidade associada à sua identidade pessoal que os mostra como vítimas de diferentes torturas e assédios, e desprovido de interesses, compromissos e lutas. Com o tempo, a filiação política é restaurada aos presos desaparecidos, e eles são abordados como sujeitos enquadrados em lutas ideológicas e interações sociais, desta forma a identidade do sujeito torna-se mais complexa, e eles são abordados como um ator social contextualizado. 
O corpus de audiovisuais documentários que representam os julgamentos pela violação dos direitos humanos durante a ultima ditadura cívico- militar em Argentina está constituída por: "Señores, ¡de pie!" (1986); "El juicio" (1989); "El juicio que cambió al país" (1995); "ESMA: el día del juicio" (1998); "Juicio a las Juntas. El Nüremberg argentino" (2002); "Los días del juicio" (2010); "Proyecciones de la memoria" (2011).

Neste artigo se investigará a construção da identidade do sobrevivente, a partir da análise de esses registros audiovisuais, abordando-o como sujeito coletivo, entendendo que a reflexão sobre os sobreviventes é necessária como tarefa para o passado, mas também, em busca do presente, dos direitos humanos, justiça e memória.

Palavras chave: identidade - sobrevivente - documentário - representação - julgamento.

[Las traducciones de los abstracts fueron supervisadas por el autor de cada artículo] 